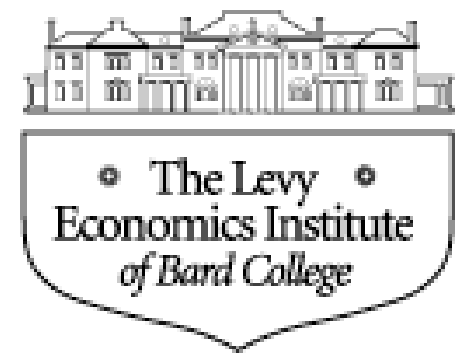

Working Paper No. 583

\title{
The Euro and Its Guardian of Stability: The Fiction and Reality of the 10th Anniversary Blast
}

by

\author{
Jörg Bibow* \\ Skidmore College and The Levy Economics Institute
}

November 2009

* Department of Economics, Skidmore College, 815 N. Broadway, Saratoga Springs, NY 12866; e-mail: jbibow@skidmore.edu; homepage:

http://www.skidmore.edu/ jbibow/index.htm. The author would like to thank the participants in the conference "The Political Economy of Central Banking / La Politique Economique et la Banque Centrale," held in Toronto, Canada, May 27-28, 2009, for their helpful comments.

The Levy Economics Institute Working Paper Collection presents research in progress by Levy Institute scholars and conference participants. The purpose of the series is to disseminate ideas to and elicit comments from academics and professionals.

The Levy Economics Institute of Bard College, founded in 1986, is a nonprofit, nonpartisan, independently funded research organization devoted to public service. Through scholarship and economic research it generates viable, effective public policy responses to important economic problems that profoundly affect the quality of life in the United States and abroad.

\author{
The Levy Economics Institute \\ P.O. Box 5000 \\ Annandale-on-Hudson, NY 12504-5000 \\ http://www.levy.org
}

Copyright (C) The Levy Economics Institute 2009 All rights reserved. 


\begin{abstract}
This paper investigates why Europe fared particularly poorly in the global economic crisis that began in August 2007. It questions the self-portrait of Europe as the victim of external shocks, pushed off track by reckless policies pursued elsewhere. It argues instead that Europe had not only contributed handsomely to the buildup of global imbalances since the 1990s and experienced their implosive unwinding as an internal crisis from the beginning, but that it had also nourished its own homemade intra-Euroland and intra-EU imbalances, the simultaneous implosion of which has further aggravated Europe's predicament. To keep its own house in order in the future, Euroland must shun the outdated "stability oriented" policy wisdom inherited from Germany’s mercantilist past and Bundesbank mythology. Steps toward a fiscal union to back the euro are also warranted.
\end{abstract}

Keywords: Economic and Monetary Union; Euro; European Central Bank; Global Imbalances; Global Crisis; Intra-area Imbalances; Competitiveness Positions; Policy Coordination; Tax-push Inflation; Financial Supervision; Mercantilism

JEL Classifications: E30, E42, E52, E58, E61, E63, E65, F36 


\section{INTRODUCTION}

As the tenth anniversary of the euro's launch neared, European Union (EU) policymakers felt they deserved to be in celebratory mood. Economic growth in the core of Europe had finally picked up in 2006 and the dark clouds that had appeared in the seemingly bright blue sky since August 2007 were believed to pass by Europe’s “zone of stability” thanks to diligently pursued stability-oriented macroeconomic policies that had steered the union away from "global imbalances" elsewhere in the world economy. EU Commissioner for Economic and Monetary Affairs Joaquín Almunia (2008) probably captured the mood of European pride about being a "pole of stability for the global economy" well when he declared in a foreword to the official “euro@10” success story volume that must have been written early enough in the year:

"A full decade after Europe's leaders took the decision to launch the euro, we have good reason to be proud of our single currency. The Economic and Monetary Union (EMU) and the euro are a major success. For its member countries, EMU has anchored macroeconomic stability, and increased cross border trade, financial integration and investment. For the $\mathrm{EU}$ as a whole, the euro is a keystone of further economic integration and a potent symbol of our growing political unity. And for the world, the euro is a major new pillar in the international monetary system and a pole of stability for the global economy. As the euro area enlarges in the coming years, its benefits will increasingly spread to the new EU members that joined in 2004 and 2007.”

As party time arrived on January 1, 2009, the European economy was in free fall and speculations about an imminent breakup of "Euroland" (officially: "euro area," the group of EU countries that have adopted the euro) soared in financial markets. Somebody must have taken the punch bowl away all too early, but who? While one set of illusions concerning Euroland as an island of stability in a stormy sea were brutally shattered, another set of illusions still prevails among key European policymakers: the view of Europe as the victim of external shocks, unfairly pushed off track by reckless policies pursued elsewhere.

This paper sets out to question and demolish these unfounded beliefs. It argues that Europe had not only contributed handsomely to the buildup of global imbalances since the 1990s 
and came to experience their implosive unwinding as an internal crisis from the beginning, but had also nourished its own homemade intra-Euroland and intra-EU imbalances, the simultaneous implosion of which further aggravated Europe’s predicament—striking as a "triple whammy” perfect storm. Contrary to the naïve idea of quickly returning to proven precrisis stabilityoriented policy wisdom, the analysis in this paper suggests that those stale ideas that inspired the policy regime of EMU agreed in upon Maastricht in the early 1990s (or: "the Maastricht regime”) should better be trashed to avoid a continuation of malperformance. Apart from the paramount problem of leaders who are the slaves of defunct spirits whose thoughts are wholly unsuitable for Europe today, one complicating factor is that the legacies of intra-European imbalances will make a fresh start so much more difficult. Another is that the global environment may be less favorable than during the first ten years and provide headwinds rather than tailwinds.

The focus of the analysis will be on the role of the European Central Bank (ECB) and the “Eurosystem” (i.e., the decentralized central bank system including the ECB and the national central banks [NCBs] of EU member states that have adopted the euro) as the guardian of the euro's stability. The analysis starts in section 2 with an overview of the policy regime underlying Europe's EMU, highlighting the regime's peculiarities and crucial deficiencies while focusing on the pivotal role of the Eurosystem. The regime’s historical origins in German ideas and Bundesbank mythology are then explored in section 3. The analysis of Euroland's performance under the Maastricht regime prior to the global crisis is the subject of section 4, while section 5 investigates how Europe has coped since. Section 6 concludes.

\section{THE MAASTRICHT REGIME OF EMU AND THE EURO'S GUARDIAN OF STABILITY}

Nearly 11 years after its launch on January 1, 1999, Europe’s “single currency” is shared by only 16 of the 27 European Union (EU) member states. Some old (i.e., pre-2004 enlargement) EU members, either by law (i.e., “opt-out clause,” UK, and Denmark) or practice (Sweden), continue to hold on to their national currencies. While four of the new EU members have adopted the euro (Slovenia, Malta, Cyprus, and Slovakia), the majority have yet to meet the entry conditions to be admitted to the exquisite euro club. Suffice to mention that not all European countries are EU 
members and may not even currently aspire to become such, with prominent nonmembers including Switzerland and Norway. Meanwhile the euro has come to play a significant international role in the union’s neighboring region (including Russia).

In discussing the political economy of central banking in Europe, two questions need to be distinguished. One is whether a common currency may or may not make sense in principle for Europe or particular countries. Another-related, but distinct-issue is whether the particular regime of EMU chosen as the foundation of the euro is likely to foster its members' economic fortunes in sustainable ways, even if the first question were answered in the affirmative. My focus in what follows will be on the latter issue: to highlight the peculiarities of the "Maastricht regime” of the EMU in guiding economic policies, foremost in those countries that have already adopted the euro, but also to a degree in countries that aspire to do so, and with wider regional and global ramifications, too; for regime flaws, rather than the idea of a common European currency as such, are to blame for Europe's malaise.

The Maastricht regime is truly special and unique in featuring a federal supranational monetary authority paired with national fiscal authorities. Reflecting the fact that the EU is not a proper political union, there is no common federal budget (to speak of) and, in fact, no European state standing behind the common currency that member states agreed to share control over. In other words, member states agreed to surrender their monetary, but not their fiscal, sovereignty. This divorce between money and the state (and public finances) has always seemed alien and troublesome from a Chartalist perspective (see Goodhart [1998]), contrasting with optimum currency area theorists’ preoccupations with market rigidities that are held to hinder the smooth functioning of a common market sharing a common money (money being associated with the market rather than the state from this mainstream perspective).

The designers of the Maastricht regime went through quite some trouble to conceive of safeguards that would really ensure this peculiar divorce and envisioned the water-tight separation between monetary and fiscal policies. In particular, the ECB, as well as the NCBs of (all) EU member states - together forming the European System of Central Banks (ESCB), as distinct from the Eurosystem - are prohibited from providing credit facilities to Europe's fiscal authorities or "monetizing” public debt through direct purchases of public debt securities. To further protect "the printing press," constraints were put on public debt financing, too. In 
particular, budget deficits exceeding 3 percent of GDP are generally deemed "excessive" and offenders will normally face penalties under the "excessive deficit procedure" (EDP) unless they can claim special circumstances for erring from the prescribed path of fiscal virtue. The principles of fiscal virtue laid out in the Maastricht Treaty were further underscored by the socalled Stability and Growth Pact (SGP), which requires members to attain a budget "in balance or in surplus” over the cycle. Finally, to protect the national partners from each other's fiscal failings, a "no bail-out" clause was included in the treaty, supposedly containing any national solvency issues at the respective national level at which they might arise.

All this was held to make the euro currency super sound and protect its guardians of stability—central bankers—-from any conceivable political interferences, including fiscal pressures. Given all this revealed distrust of (elected) politicians, it is of course quite ironic that Europe's (unelected) central bank politicians are not facing any effective discipline at all-a situation I dubbed the "Maastricht paradox" (Bibow 2002). As no effective check was put in place to balance the ECB's authority (or whim), it is probably fair to say that the ECB is the world's most unconstrained (i.e., independent and unaccountable) central bank. The bank publishes reports, holds regular press conferences, and its chairman engages in a "monetary dialogue" with a subcommittee of the European Parliament, but none of this publicity has any "bite" in the sense that the bank might face any real consequences for its own (mis)conduct.

Essentially the euro is managed by a federal supranational central bank that is not properly accountable to either national or European political authorities. The guardian's mandate, as laid down in the treaty, is to "maintain price stability" and, without prejudice to this primary objective, to contribute to the achievement of other objectives pursued by the union (such as growth and employment). No doubt this mandate offers central bankers an enormous degree of independence, i.e., discretion, in interpreting "price stability" and how to attain it, and in deciding what may constitute risks to this primary objective (and thus circumscribe the bank's support for any other goals). Moreover, and perhaps most importantly, the ECB's peculiar form of central bank independence is enshrined in the treaty, which means that the ECB also enjoys the virtual absence of credible threats to have its constitution changed.

By purposeful design there is thus a clear dominance of central bankers and monetary policy within the Maastricht regime. In fact, not only does it lack a federal euro treasury, there is 
not even any proper coordination of national fiscal policies beyond the asymmetric constraints placed on national policies arising from the SGP and the "multilateral surveillance" process conducted under the auspices of the European Commission and the EU's Council of (Economics and Finance) Ministers (Ecofin). ${ }^{1}$ As a result, “Euroland's overall fiscal stance is not deliberately set—so as to help stabilizing domestic demand in Euroland as a whole-but essentially the random outcome of national budget plans” (Bibow 2007c: 303). Asymmetrically constraining national fiscal policies by deficit ceilings also compromises member states’ only remaining policy instrument for dealing with asymmetric shocks. A further implication is that, beyond the working of the build-in stabilizers (and even more so if the stabilizers are not actually allowed to work automatically), monetary policy has to shoulder the main burden in countering common shocks. In line with the supposed dominance of monetary policy over fiscal policy and primary concern with central bank independence, the macro-policy mix is left to the central bankers. In essence, the Maastricht regime has no one "minding the store” (i.e., stabilizing domestic demand and employment) unless central bankers—as benevolent dictators—choose to do so.

Relations between the monetary and fiscal/political authorities also concern exchange rate policy vis-à-vis non EU members, an area in which the Maastricht regime has left a peculiar vacuum. The possibility of "general orientations" to be laid down by finance ministers under certain conditions is mentioned in the treaty, but in practice any political influence on the euro's exchange rate is largely left to the actual interaction of the players involved. By words, both the ECB and the Eurogroup have laid claim to their primacy. The ECB seems to have gained the de facto upper hand in an area that elsewhere is clearly under the control of the political authorities. For one thing, the vacuum of legal responsibility and the resulting ambiguity in practice may jeopardize one of the euro's key original motivations, namely that of acting as a protection shield against external developments. For another, this ambiguity also undermines Europe’s part in global policy coordination. At the regional level the exchange rate issue also matters greatly to aspirants of euro adoption, as one of the entry criteria is the two-year participation in the revised (euro-centered) exchange rate mechanism (ERM2).

A no less critical issue for Euroland members actually concerns intra-Euroland “exchange rates.” For while nominal exchange rates between members have of course ceased to

\footnotetext{
${ }^{1}$ While Ecofin includes economics or finance ministers from all EU member countries, the Euroland subgroup of such ministers is called the "Eurogroup."
} 
exist with the euro, competitiveness positions (or real exchange rates) are still liable to change, namely when wage and/or productivity trends diverge within the union. Like fiscal and social policies, wage policies in Euroland also remain a national affair, since wages are agreed by national "social partners" (and perhaps under guidance of national policymakers). Effectively, national wage trends-by determining relative unit labor costs-have become the equivalent to intra-Euroland exchange rates. It is thus quite ironic that coordination is conspicuous for its absence in this area given that intra-area exchange rates were supposed to be a "matter of common concern” since the beginnings of European integration.

Instead, Europe’s policymakers cherish the romantic idea that "liberalized" and "flexible" markets would generate any required adjustments on their own and without any further policy interferences with market forces. Guided by the "principles of an open market economy" and to raise and unleash Europe's growth potential in full, the whole focus of the EU's policy agenda has been to foster market flexibility. Ever since the "single market programme" of the 1980s, and no less so with today’s “Lisbon Agenda,” the EU Commission has been the champion of Europe's peculiarly one-sided "structural reform” policy orientation. In conjunction with the ECB's stability-oriented (price-stability-only) policy focus, micro reforms are apparently held to deliver not only micro efficiency, but macro stability, too. Market liberalization and integration are of course two sides of the same coin. While creating a common European market has indeed made great progress since the 1980s in many areas, including financial integration, policy integration (or harmonization or even coordination), in some areas-including prudential supervision of pan-European financial institutions - it is still peculiarly lacking today.

Prudential supervision has remained foremost a national prerogative, just as the ultimate responsibility for financial stability in general rests at the national level, too. This reflects the fact that in the absence of a fiscal union, solvency problems of European financial institutions could only be addressed at the national, rather than the union, level. This has left vital union-wide systemic questions unanswered and the ECB once again fits oddly into the overall governance system. In monetary policy matters, the politically unchallengeable ECB stands supreme as the supposed cockpit of the Eurosystem. By contrast, regarding financial stability policy, while the NCBs may play varying roles in their respective national financial system realms, in practice the treaty merely asks the ESCB to "contribute to the smooth conduct of policies pursued by the 
competent authorities relating to prudential supervision of credit institutions and the stability of the financial system," mentioning almost in passing that "specific tasks concerning policies relating to the prudential supervision of credit institutions may be conferred upon the ECB.” In the absence of more explicit responsibilities regarding financial stability policy, it has once again been left to the ECB to decide whether and how to fill the systemic void, should such need arise, using the monetary policy instruments and powers at its disposal.

Additional complexity in this area arises from the fact that the UK, hosting Europe's foremost global financial center in London, remains outside Euroland to this day (and for the foreseeable future), so that the Bank of England, while not part of the Eurosystem, is bound to feature prominently in the ESCB (depending on whatever responsibilities the British authorities may assign to the bank in the financial stability arena). Further scope for ambiguity once again relates to the fiscal issue; given the general practical difficulty of distinguishing liquidity and solvency problems, the ECB's position as a “lender of last resort” is inevitably a particularly delicate one. If emergency liquidity provisions to individual institutions were to haunt the bank as “solvency support turned sour,” i.e., central bank losses, the ECB could find itself negotiating its own recapitalization with national finance ministers - the very nightmare of compromising the ECB's independence that the designers of the Maastricht regime were so keen to rule out completely. Perhaps too firmly believing that price stability cum liberalized markets would guarantee both macro stability as well as financial system stability, the regime designers overlooked the fact that Europe's supposedly integrated financial system would be made especially vulnerable at the systemic level for all those fiscal "safeguards,” lacking both integrated financial supervision and a lender of last resort with a guaranteed fiscal backstop, i.e., “deep (Treasury) pockets.”

After highlighting the fact that the Maastricht regime of the EMU with the Eurosystem at its core features important peculiarities, it is now time to emphasize that the euro's guardian of stability has interpreted its special role in rather peculiar ways. In fact, from its inception, the ECB, the Eurosystem's cockpit, has expressed rather idiosyncratic views on monetary policy. In particular, the ECB has been adamant in emphasizing it was not in the business of inflation targeting. Instead, the ECB offered its “definition” of price stability as “a year-on-year increase in the Harmonized Index of Consumer Prices (HICP) for the euro area of below 2 percent” to be 
maintained "over the medium term" (ECB 1999), a definition later "clarified" as the aim of maintaining inflation "below but close" to 2 percent over the medium term. The ECB devised a "two-pillar stability-oriented" policy strategy, which, in its revised form, includes an "economic analysis" of a variety of fairly conventional short-term economic indicators to be "crosschecked" by a "monetary analysis" featuring the broad monetary aggregate M3. ${ }^{2}$ Together the two pillars are supposed to enable the ECB to assess the medium-term outlook and risks to price stability, and to communicate its assessments and policy decisions to interested observers.

The more obvious contrasts to conventional inflation (forecast) targeting are to be seen in the fact that the ECB has failed to provide an explicitly symmetric price stability definition and that policymakers refuse to own what the bank publishes as its regular "staff projections." These differences provide revealing hints concerning the ECB's notorious asymmetry in approach and preference for retaining its scope for discretion. It would be only fair to add here though that at least the latter characteristic is broadly shared by the U.S. Federal Reserve, which, until recently, did not provide any definition of price stability either. In any case, the crux of the matter is rooted in contrasting policy mandates and their respective interpretations. Whereas the Fed was given a "dual mandate" that makes it very hard for the Fed to deny responsibility for rising U.S. unemployment in case of recession, the ECB's mandate, by clearly prioritizing price stability, opens the door for the bank to deny any such responsibility if risks to its primary objective are believed to exist.

This leads us to the less obvious difference between the ECB's "stability-oriented" approach and inflation (forecast) targeting. Given that the latter approach prioritizes the attainment of the inflation target over other objectives, the key contrasting feature only emerges when policymakers' understanding of the relationship between price stability (or inflation) and other objectives is taken into account. In inflation targeting, the base case relationship is of a Philips curve type, which at least by enlightened mainstream researchers and policymakers is acknowledged to be rather flat at low levels of inflation (see Begg et al. [2002], for instance).

\footnotetext{
${ }^{2}$ As with much else (see next section), the historical background to the ECB's "monetary pillar" is to be seen in the Bundesbank's "monetary targeting" strategy. In both cases, and contrary to its apparent monetarist inspiration, the primary purpose was to increase central bankers' discretion. In more recent years the ECB started to justify its monetary analysis as an early warning system for the buildup of financial fragility and, in view of the current crisis, the ECB has added some spin to these claims. Politics and public relations aside, this is begging the question of why the ECB failed to identify the systemic risks stemming from soaring internal imbalances in Euroland and the EU; see Bibow (2005).
} 
The situation is very different at the ECB, which professes an acute dislike for any "output gap" measure. At issue is much more than just difficulties of measurement, which undoubtedly exist in this regard - at issue is an outright rejection of "fine tuning" the economy. A "medium-term approach" to maintaining price stability by a "non-activist” policy is what the ECB claims to aspire to. From the ECB's perspective, any concern for stagnant output, apart from its potential relevance for maintaining price stability "in the medium term," would be wholly misguided (see Bibow [2004] for further discussion).

The ECB has therefore presented an "elegant” solution to fulfilling its official treaty obligation to contribute to objectives other than price stability, namely that by maintaining price stability the ECB quite simply fulfils its job in total since, in the ECB's view, “maintaining price stability in itself contributes to the achievement of output and employment goals” (ECB 1999: 40 , emphasis added). On the occasion of a monetary dialogue session, at which the ECB is supposedly "held to account," the ECB's first president Wim Duisenberg, who also used to refer to price stability as the ECB's “sole” objective, explained that "we always maintain—and we still do - that the best contribution that monetary policy can give to fulfill that second task is to maintain price stability” (Duisenberg 2001). Quite similarly, the ECB’s current president, JeanClaude Trichet, more recently reiterated that "there is one needle in our compass and it is price stability” (Doland and Waki 2008).

Mainstream researchers have yet to come to grips with what lies behind the ECB's approach and mindset. A Center for Economic Policy Research (CEPR) report of 2002 provides a telling example:

\begin{abstract}
"In this remarkable interpretation of the treaty, the ECB fulfills its double mandate by reducing it to a single responsibility, a focus solely on price stability. All other objectives are then realized automatically. In this view the ECB cannot be held responsible for what happens in the real economy. We consider that this view is not just narrow, but mistaken.” (Begg et al. 2002: 12)
\end{abstract}

I will have more to say on this vital issue below. Here we summarize that essentially, in the ECB's view, price stability somehow causes growth. If the economy refuses to grow while price stability is maintained, this cannot possibly constitute any additional responsibility for 
monetary policy. Instead, potential sources behind such malperformance include structural problems, ill-guided fiscal policies, or irresponsible policies and shocks originating in the rest of world.

Today, the ECB's view is also Europe’s official view, with the European Commission representing the other proponent of the policy wisdom that a sound combination of confidenceboosting structural reforms and confidence-boosting "stability-oriented” macro policies will deliver the best of all worlds. In fact, key officials profess sufficient confidence in this peculiar wisdom to announce that the world at large would be best served by following Europe's model. For instance, just days before the Lehman collapse, EU Commissioner Joaquín Almunia announced: "I would be very happy if other central banks would follow the same criteria as the ECB in preserving price stability” (Dinmore and Thornhill 2008). In July 2008, a year after the outbreak of the current global crisis, the ECB implemented its "stability-oriented” wisdom by hiking interest rates_-alone among the world's leading central banks. The next section investigates the historical origins behind the ECB's guiding principles and Europe's official view.

\section{HISTORICAL ORIGINS OF THE MAASTRICHT REGIME: THE BUNDESBANK “SUCCESS STORY"}

Put briefly, the historical intellectual origins behind the ECB's guiding principles and Europe's official view today are all German, just as the Maastricht regime is of German design and the ECB modeled on the Bundesbank. So what we are really investigating are the historical roots of "the German view" and Bundesbank price stability mantra, and why the German view prevailed in Europe when the EMU regime was designed.

The first thing to note is that the Bundesbank's acclaimed independence arose as a historical accident. The supposed independence of the Bank deutscher Lander (BdL, the Bundesbank's forerunner) was neither imposed upon (West) Germany by the Allies, nor was it really intended in its actual form by the first federal government led by Konrad Adenauer, nor can it claim any theoretic grounding in the ordoliberal tradition of Walter Eucken (Bibow 2009a). 
The next thing to note is that in aspiring to independence, the BdL/Bundesbank developed its political instincts quickly and played its cards rather well. That central bankers were blessed with a head start vis-à-vis (West) Germany’s first federal government was probably important. Over the years, the bank successfully self-stylized itself in the public's view as the guardian of stability and host of unchallengeable economic wisdom in the country. In achieving this position, orchestrated public conflicts with the government of the day formed an important aspect in its public relations strategy (see Johnson [1998]; Katzenstein [1987]; Marsh [1992]). Rather than serving as a politically accountable team-player in any government's economic program, German central bankers took it upon themselves to play the role of opponent or even referee vis-à-vis other political actors, promoting the idea that an independent central bank would somehow be directly accountable to the general public.

Another important aspect in the public relations strategy was the nourishing of hyperinflation fears by rewriting Germany’s history. Johnson (1998: 199) refers to the Bundesbank’s “orchestrated efforts to reinsert memories of the hyperinflation of the 1920s into Germany’s postwar political mythology.” It is true that Weimar Germany suffered severe hyperinflation in 1922-23. Yet, it is also true that Germany was brutally hit in the Great Depression. ${ }^{3}$ While in the United States the national crisis led to the New Deal under Franklin Roosevelt, across the Atlantic it delivered the death blow to Weimar Germany and paved the way for the rise of Adolf Hitler and Nazi Germany, with known consequences for Europe and the world. The very real consequences of Adolf Hitler for Germany itself, apart from millions of deaths and grave destruction, included the fact that Germany ceased to exist in May 1945, to be reestablished under Allied control as two countries in 1949, which followed a currency reform in the three western zones in 1948 that had given birth to the deutschmark-the stability-oriented guardianship for which the Bundesbank (established in 1957) would become reputable.

\footnotetext{
${ }^{3}$ Keynes analyzed the consequences of inflation and deflation in his Tract, concluding that "both are evils to be shunned” (Keynes 1923: 36). Following his visit to Germany in early 1932, Keynes (1932: 366) observed:

"Germany today is in the grip of the most terrible deflation that any nation had experienced. A visitor to that country is offered an extraordinary example of what the effects of such a policy can be, carried out à outrance. ... Nearly a third of the population is out of work. The standards of life of those still employed have been cruelly curtailed. There is scarcely a manufacturer or a merchant in the country who is not suffering pecuniary losses which must soon bring his business to a standstill. ... Too many people in Germany have nothing to look forward to—nothing except a 'change,' something wholly vague and wholly undefined, but a change. ... Hamburg, living in a stupor, many miles of ships laid up silent in its harbor, with the elaborate traffic control of a great city but no traffic to be seen, is a symbol of Germany under the great deflation-a worse visitation, if it is to be continued, than even the great inflation was a few years ago."
} 
Financially the Federal Republic of (West) Germany started with a fresh balance sheet, a new currency, a cleaned-up banking system, and little public debt.

It is surely remarkable that while memories of the Great Depression are still haunting U.S. policymakers today, the Great Depression seems to have been deleted from the collective German memory — despite the fact that Germany was hit equally hard as the United States. Instead, German history—as propagated by independent central bankers—apparently featured two hyperinflations. First, there was the actual one that I referred to above, but then there allegedly was a second one following Adolf Hitler—suppressed while he was still inflicting his mass destructive lunacies - which then hit German savers with a lag, who thereby lost their savings once more in one generation. The picture of inflation, deflation, war, and losses is getting seriously distorted. In view of the unspeakable monstrosities and immeasurable grief that Nazi Germany brought upon mankind, it is surely nothing but embarrassing that German public figures should even mention those "poor" German savers who tragically lost their savings, of all things material or breathing, in those events. Just imagine someone who, say, as the driver of a driver killed three children sitting in the backseat through "experimental driving" to then mention to the surviving father (who happens to be his neighbor and still tries to be his friend and partner) how very tragic it was, from the driver's perspective, that his favorite tie got ruined in that event. What a scoundrel tribute to German savers to declare Nazi Germany’s “Total War” a monetary phenomenon!

I can see who this kind of disgraceful historical fiction might have served rather well. In this conveniently redrafted history it was the Weimar hyperinflation that led straight to Hitler and another (suppressed) hyperinflation, with the Great Depression written out of the picture. It may then appear as if Germans might really have some justification in feeling neurotic about inflation, and every reason to adore the stability-oriented guardian who defends them against yet another hyperinflation, the threat of which is apparently ever-present. ${ }^{4}$ German policymakers are notorious for seeing inflation risks everywhere while showing no concern whatsoever for threats

\footnotetext{
${ }^{4}$ For instance, former Bundesbank president Hans Tietmeyer (1991: 182) declared: "The reasons for the success of German monetary policy in defending price stability are in part historical. The experience gained twice with hyperinflation in the first half of this century has helped to develop a special sensitivity to inflation and has caused the wider public to believe in the critical importance of monetary stability in Germany. For this reason, the strong position of the Bundesbank is widely accepted by the general public - questioning its independence even seems to be a national taboo. This social consensus has yielded strong support for the policy of the Bundesbank.” See also Giersch and Lehment (1981).
} 
of deflation and repeat of the Great Depression experience. Only one thing is on the German mind, it seems: (hyper)inflation.

This leads me to the key peculiarity about German-style monetary policy: a conspicuous asymmetry in mindset and approach. The ECB may be portrayed as a driver who is quick to slam the brakes, but highly reluctant to ever use the accelerator, with this asymmetric driving style giving rise to an "antigrowth bias.” Historically, this peculiar policy style may be traced back to Germany’s acclaimed independent central bankers. Start with Wilhelm Vocke, for instance, member of Directorate of German Reichsbank from 1919-39 and president of the Directorate of the BdL from 1948-57, who then became the first Bundesbank president in 1957. In his memoirs, Vocke (1973) categorically declared that "every inflation starts in public finances as public expenditures get inflated.” While Vocke seems to have distilled all his wisdom from Germany’s notorious hyperinflation past, Otmar Issing, chief economist of the Bundesbank from 1990-98 (who then went on to hold that position at the ECB in its critical formation years from 1998-2006), was also fond to recall the lessons from the 1970s, observing that: “Artificially stimulating the economy by large budget deficits and/or inflationary monetary policy is no viable option. In fact, history tells us that such policies can only provide temporary straw fires, with potentially damaging long-term consequences” (Issing 2003).

Issing's point concerns fine tuning and the supposedly superior nonactivist medium-term approach he favors. Note however that there appears to be nothing artificial about choking the economy, which becomes quite naturally necessary whenever "stability-oriented” central bankers believe inflation risks to require such activist policy reaction. The real question then becomes how this kind of asymmetry could possibly not give rise to an antigrowth bias.

To address this conundrum and understand why Germany's monetary anthem of “price stability above all else” actually worked for both the country and the Bundesbank, one needs to account for international and regional monetary arrangements and the behavior of Germany's trading partners. (Western) European reconstruction and recovery following World War II started out within the Bretton Woods regime of exchange rates pegged to the U.S. dollar. It did not take long for Europe to start thinking about alternatives that would make exchange rates within Europe even more stable, while making Europe less dependent on the United States. The interwar experience of "beggar-thy-neighbor" competitive devaluations provided the background 
to this craving for stable exchange rates. While earlier initiatives did not come to much, the establishment of the European Monetary System (EMS) in the late 1970s marked the starting point of the process that led to Europe's Economic and Monetary Union (EMU) as we know it today.

Within German “stability culture,” the Bundesbank’s part was to enforce discipline, both budgetary discipline and wage discipline. The result was not only low inflation, but inflation lower than inflation of Germany's trading partners and that is an important factor within any system of pegged nominal exchange rates: over time a country with relatively low inflation gains in competitiveness which boosts its export performance. Stability-oriented policy worked well under the Bretton Woods regime, establishing both Germany’s export-oriented growth strategy and the Bundesbank's claim to fame as inflation fighter.

Essentially, the establishment of the EMS then recreated the same conditions within Europe in the 1980s. As Europe pegged its currencies to the deutschmark while still having significantly higher inflation, rising competitiveness again fired Germany’s export motor and the country ran up a 5 percent of GDP current account surplus over the 1980s.

Another factor is important here. In the late 1970s, Germany had for once bowed to international pressures and agreed to act as a "locomotive" and applied fiscal stimulus. As inflation soared with the second oil price shock, the outcome was judged a policy failure. This is quite typical for habitual references by German policymakers. Issing's above "straw fire” remark refers to this episode as an experience never to be repeated. In fact, with the change in government in 1982 Germany officially ended any attempt at demand management, with balancing the budget attaining policy priority. The predictable result was domestic demand stagnation and rising unemployment. What rescued Germany in the first half of the 1980s was the Reagan expansion and strong U.S. dollar. The export motor was then sustained in the second half of the 1980s as the competitiveness gains within the EMS came through. Germany ended the decade not only with a large current account surplus, but also with a balanced budget.

Bundesbank virtues of stability and discipline thus found all the support they needed within the German political elite when it came to laying down the right policy regime for Europe. What works for Germany will also work for Europe. In fact, they must have thought that if everybody were to adopt German stability culture things would work even better for everyone. 
In Germany, price stability and fiscal discipline caused growth, it seemed, when actually it was relative price stability that did the trick.

Why did Europe accept the "made in Germany" Maastricht regime? I said above that the EMS provided the starting point of what became the EMU. By intention and design, the EMS was supposed to be a "symmetric" system of equal partners, bestowing no special status on any particular country or currency to act as “anchor,” but constructing the synthetic European Currency Unit as a basket of participating currencies instead. Ideals of equality were one thing; in reality, the EMS evolved into a larger deutschmark zone over the course of the 1980s, with the Bundesbank pulling the monetary shots in Europe.

It is easy to see that Germany’s larger European partners did not really appreciate this outcome and came to see EMU as their best option to partly regain monetary sovereignty, namely by establishing shared control over a common European currency. German monetary hegemony in Europe was not a politically tolerable long-term solution, particularly after German unification - an event that may have accelerated EMU. Nor was it economically sound to have a central bank with the mandate to maintain price stability in Germany set monetary policy for Europe. Yet, given the deutschmark's anchor role within Europe, Germany was, de facto, the only country left to yet surrender its monetary sovereignty and therefore was in a strong bargaining position. For domestic political reasons, Helmut Kohl, German Chancellor at the time, had to make sure to have the Bundesbank “on board,” as selling the euro to the German populace would hardly have been possible without public sanctioning by the trusted guardian of the beloved deutschmark. This meant the Bundesbank could dictate the conditions of its own abdication of monetary rule over Europe. The conditions it laid down were such that probably even the Bundesbank itself considered it unlikely that Europe would swallow them. That Europeans did so after all is foremost a reflection of their yearning to overcome Bundesbank supremacy.

As a result, Euroland members today share sovereignty in monetary control, but much of Europe ended up operating under a central bank single-mindedly focused on maintaining price stability and national finance ministers who are constrained in making a balanced budget the primary goal of their policymaking. The euro is a currency without a state or federal treasury backing it. In this regime, monetary policy has no role in stabilizing the economy apart from 
maintaining price stability; national fiscal policies have no such role to play either, apart from whatever support might come from built-in automatic fiscal stabilizers. It is not the economy, but policy itself, that needs to be stabilized. Germans like to speak of "stability policy" rather than stabilization policy. "Blinded by success," German policymakers failed to understand that they were begging for trouble by asking others to follow the German model — the workability of which depends precisely on others behaving differently. ${ }^{5}$

\section{EUROPE'S (MAL)PERFORMANCE UNDER THE MAASTRICHT REGIME}

From a Keynesian vantage point, the conditions for the Maastricht regime to work at all for Euroland may be identified as follows: monetary policy would have to boost domestic demand sufficiently to prevent fiscal policy from becoming too much of a drag, the global environment and euro exchange rate needed to be benign, and wage trends and structural reforms had to be such as not to create serious intra-area imbalances either (Bibow 2001; Kregel 1999). In actual fact, these conditions have not been met consistently since the 1990s and Euroland's economic performance has proved correspondingly disappointing. Unsurprisingly, in view of its center role in the play, the ECB bears the foremost responsibility for this outcome.

This section singles out three prominent cases of malperformance or policy blunders. The first concerns Euroland's business cycle, which features brief booms, long periods of stagnation, and astonishing export dependency. The second concerns the outstandingly counterproductive way of interaction between monetary and fiscal policies in the period of protracted stagnation between 2001 and 2005, producing a phenomenon that I dubbed "tax-push inflation" (Bibow 1998, 2006). Third is that the Maastricht regime and official view have not acted as a "glue" nourishing convergence among members, but actually amplified divergences within the union in rather dangerous ways.

To begin with, exporting the German model to Europe through the Maastricht regime meant inflation would be low across Europe, while all countries would try to balance their budgets at the same time. When German stability policy was jointly applied across Europe in the early 1990s, the predictable result was domestic demand stagnation and rising unemployment.

\footnotetext{
${ }^{5}$ See Henning (1994), Kenen (1995), and Dyson and Featherstone (1999) on the route to Maastricht. For regime analyses, see also Allsopp and Vines (1998) and Arestis and Sawyer (2001).
} 
Even by 1996 it looked as though EMU was not going to fly because stagnation kept budget deficits above the 3 percent ceiling across the continent. Luckily, the U.S. "new economy” boom and strong U.S. dollar came to the rescue, and eleven countries qualified in the spring of 1998 to launch the euro in January 1999. In other words, laboring under the Maastricht constraints, Europe failed to generate sufficient homemade demand growth, but benevolent external forces allowed the euro to get off the ground just on time.

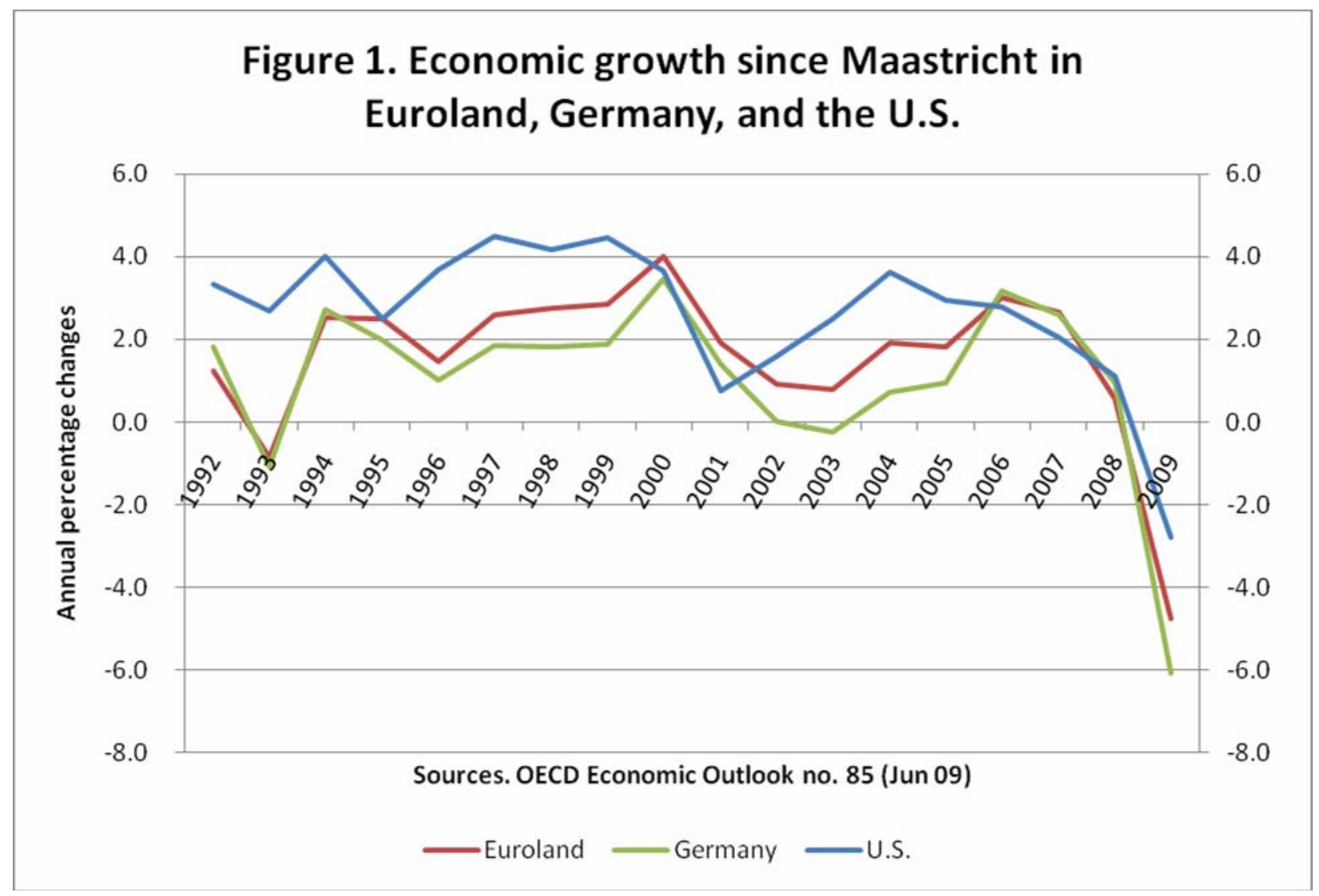

Figure 1 shows the recession in Euroland in the early 1990s following the Bundesbank's tight money crusade in response to German unification—an asymmetric shock hitting the anchor country, the monetary policy reaction to which was transmitted throughout Europe through the EMS, once more convincing Germany's partners how useful it would be to get rid of Bundesbank supremacy. Both recessions in the early 1990s and early 2000s were followed by 
protracted domestic demand weakness, most pronounced in Germany itself (as figure 2 reveals) by separating domestic demand growth and net export contributions to GDP growth.

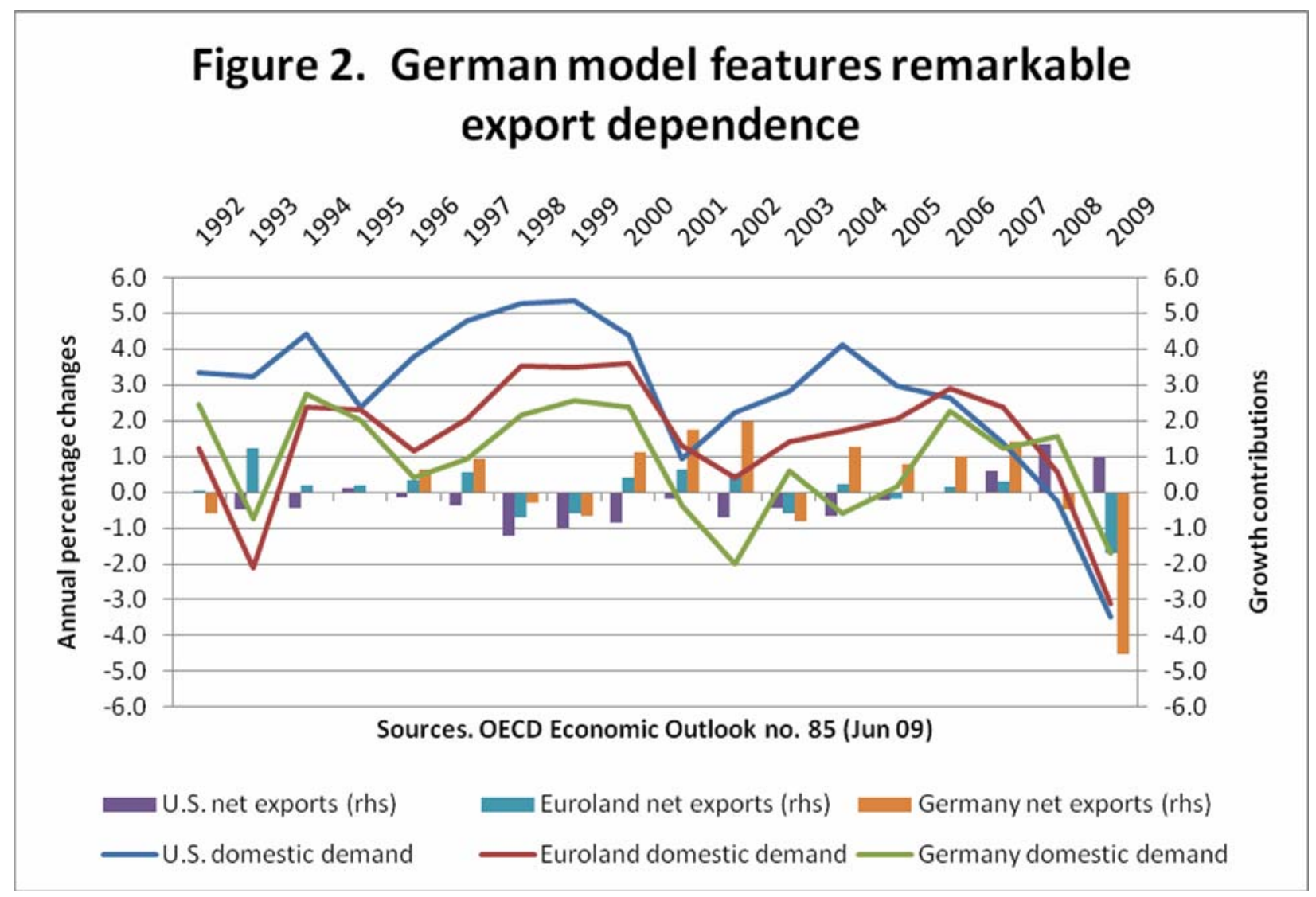

Figure 2 also shows that the euro area actually experienced a brief period of stronger domestic demand growth towards the end of the 1990s (and again in 2006-07), even as the Asian crisis meant negative net export contributions in the earlier episode. A key driving force behind this burst of growth was "interest rate convergence.” In the 1990s, as the introduction of the euro neared, interest rates in incipient member countries converged towards their lower German levels. This process provided an important temporary boost to asset prices and domestic demand in countries other than Germany, countries such as Spain and Ireland. The same kind of process was repeated in the 2000s around the time of entry of the new EU member countries in Eastern and central Europe, as the prospect of EU membership - to be followed by euro adoption — again encouraged markets to engage in “convergence play.” Between 2003 and 2008 these countries 
were the recipients of massive capital inflows, leaving uncompetitive exchange rates, asset price bubbles, domestic demand booms, and huge current account deficits in their trail. It is important to note that this is a one-off adjustment in interest rates and asset prices, which runs its course and may end in tears (see below).

It is instructive to take a closer look now at the 2001-05 period, during which "the eurozone was the sick giant of the world economy” (Wolf 2007). Figure 1 shows that Germany and Euroland participated in the 2001 "global slowdown," while figure 2 highlights that, in their case, this episode featured, above all, a collapse in domestic demand. The collapse in domestic demand followed the aggressive monetary tightening by the ECB that can be seen in figure 3, which had the unfortunate side effect of crashing the euro and thereby driving up inflation (see figure 4, below). ${ }^{6}$ With inflation pushed up in this way from its (too!) low starting level of just 0.8 percent in 1999 to above 2 percent, the ECB felt all too justified to sit tight and "wait and see" while domestic demand stagnated.

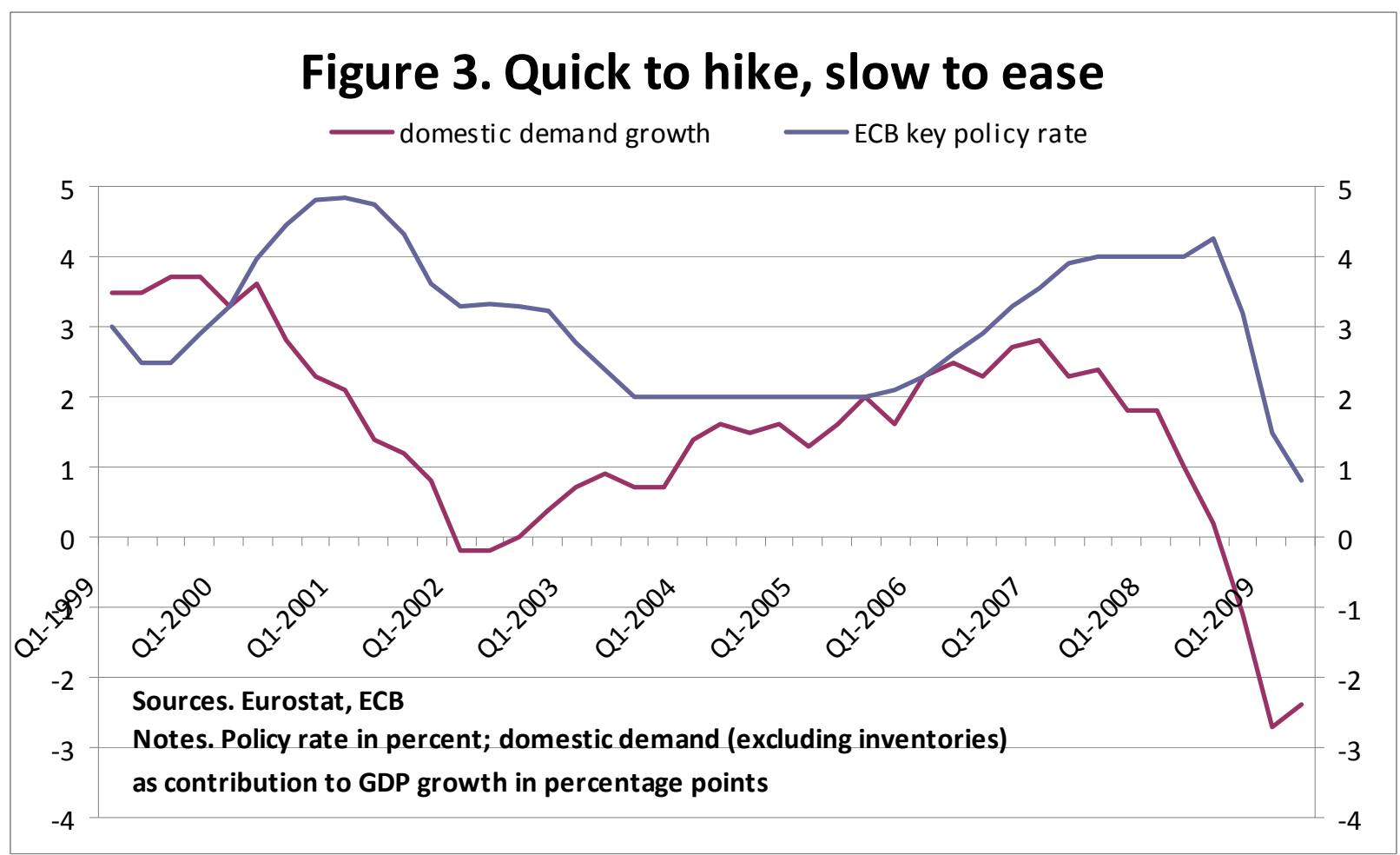

\footnotetext{
${ }^{6}$ See Bibow $(2002,2007 c)$ on the time inconsistency hypothesis of the euro's plunge. The European Commission (2000: 71) correctly foresaw actual outcomes: "To the extent that the depreciation in the euro is due to cyclical divergence between the euro area and the United States, a rise in interest rates in an attempt to support the currency could even backfire if it was perceived as stifling the euro-area recovery. The risk of creating an even more unbalanced growth pattern with weak domestic demand and higher export growth would be serious.”
} 
Alas, this nonactivist approach (or "steadyhandedness") had rather predictable consequences for public finances. As ever more member states were facing EDPs (or the threat thereof) among their widespread procyclical retrenchment measures, increases in "administered prices" and indirect taxes came to feature rather prominently, pushing up headline inflation which, in turn, meant more wait and see from the ECB. Notice the irony here: with central bankers single-mindedly focused on squeezing inflation "below 2 percent" and finance ministers single-mindedly focused on bringing the deficit "below 3 percent," by shooting each other in the knee and strangling domestic demand, the unintended consequences were to keep both inflation and deficits above their respective magical numbers. Figure 4 shows that "tax-push inflation" conspicuously contributed to headline inflation during these years of stagnation. When volatile energy and food prices are accounted for (core inflation measure 1), and especially when the stagnation-induced fiscal policy (or "tax push") contribution is also excluded (core 2), underlying inflation pressures are seen to have stayed below 2 percent throughout. Note also that "market-determined underlying inflation” (core 2) reveals a clear decline over these years, despite allegedly all-pervasive structural rigidities, which, according to myth, gave rise to inflation persistence. By design, the Maastricht regime has monetary domination built into the system, but sound central bankers should still internalize fiscal policy. As Euroland got stuck in a stability-oriented vicious circle, tax-push inflation emerged as the key symptom in a macroeconomic policy blunder that kept inflation persistently above 2 percent and domestic demand stagnant. Obsessively aiming at too much of the good thing may not pay off, but rather it may backfire. 


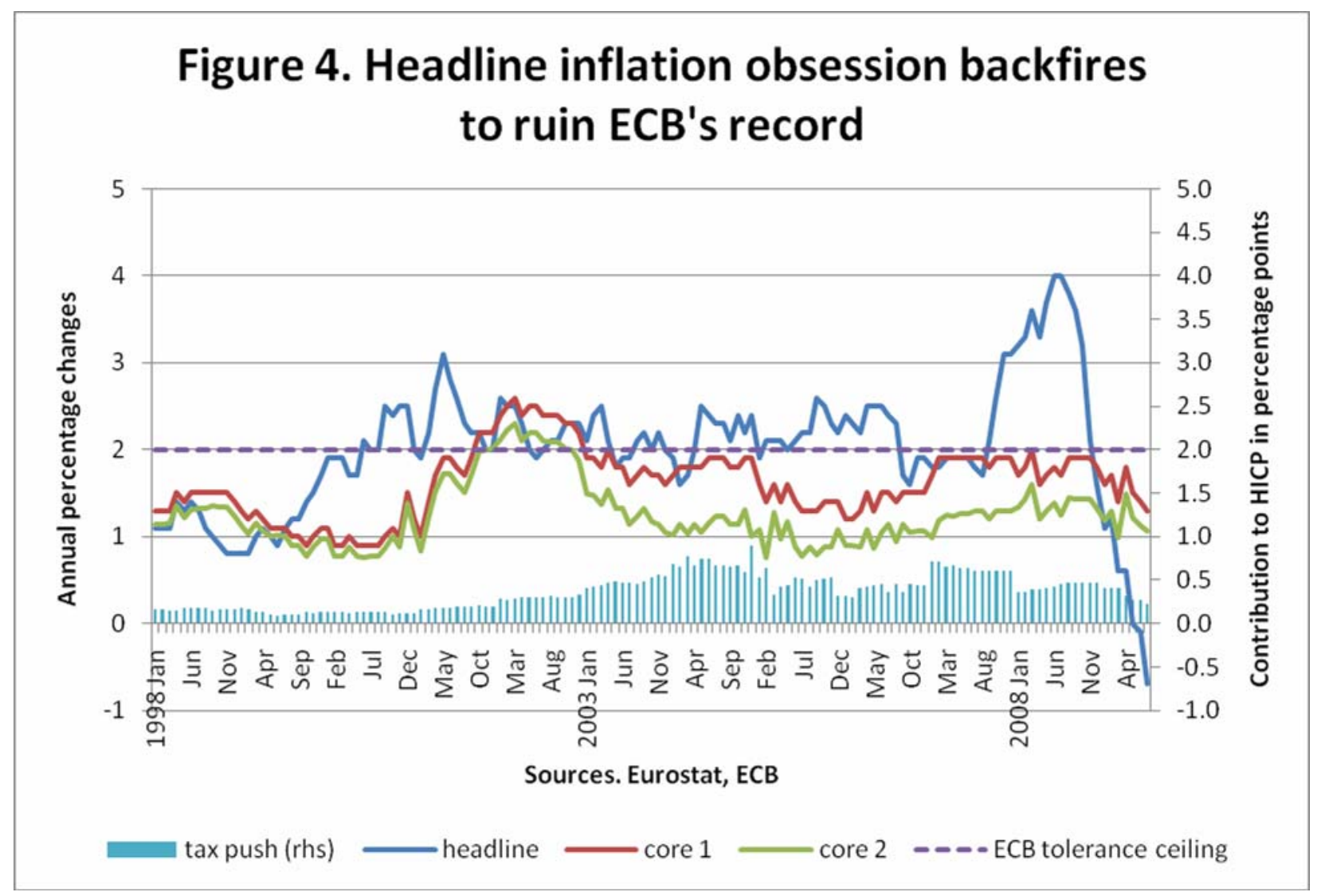

Divergence also took off during this period—marking the third key policy blunder. I mentioned the interest rate convergence process temporarily boosting asset prices and domestic demand in old EU members other than Germany (1990s) and later in the new EU members (2000s). Stimuli like these are quite inevitable when approaching a monetary union with a low inflation anchor and can be met by appropriate fiscal policies in particular. They became a problem in EMU because the anchor, Germany, was stagnating for most of the time, thereby pulling interest rates across the union lower than would otherwise have been warranted, while inflicting weak German import growth on partner countries, too. A possible reason why Germany was plagued by particularly stubborn stagnation emerges from the analysis above: the German model failed to work in its homeland, as Germany's partners converged to the German norm, shutting off the valves of Germany’s export engine by leaving Germany as part of that new common norm. 


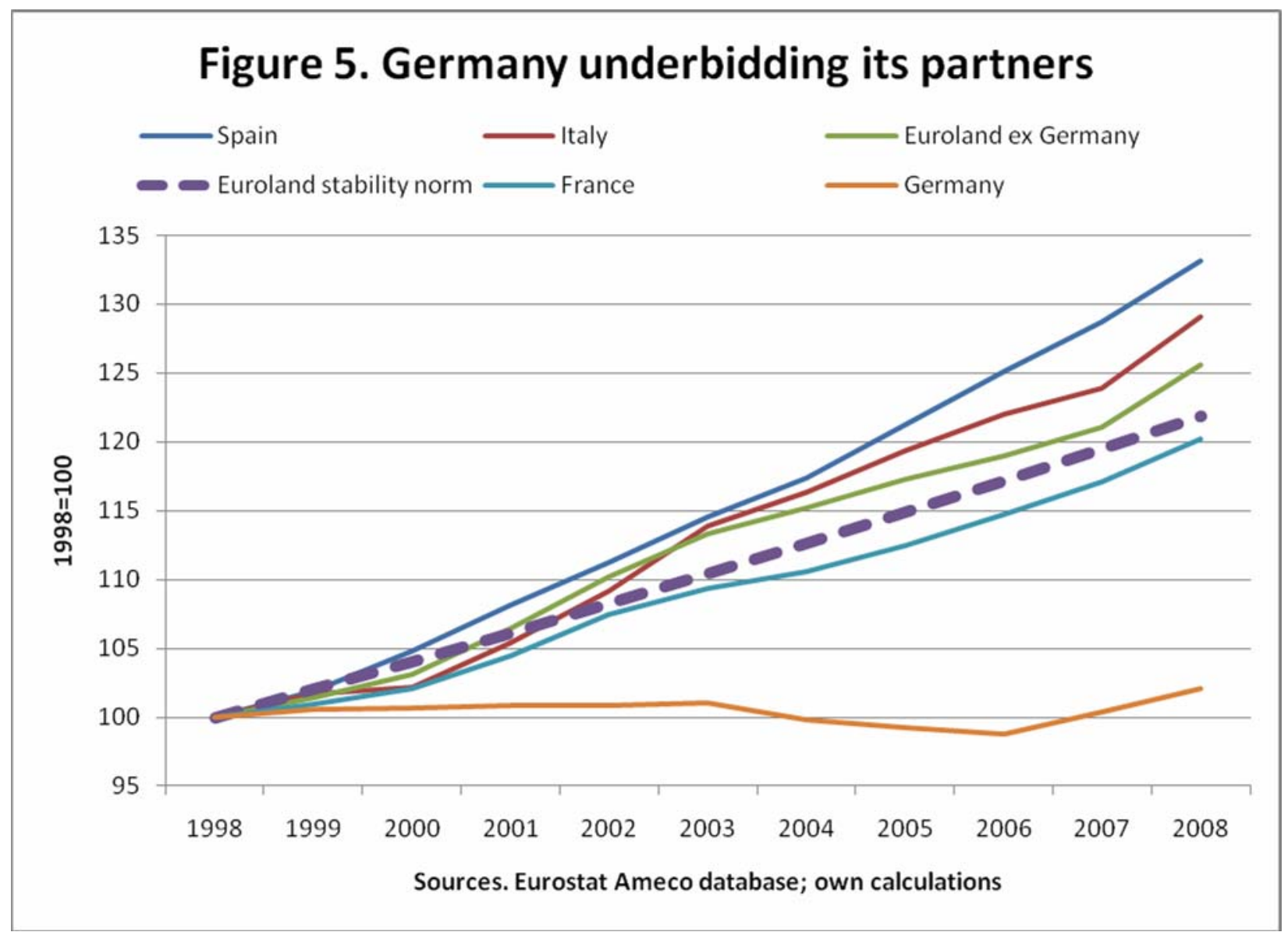

In actual fact, things were made far worse by Germany’s reaction to its sputtering export engine. Starting in the mid-1990s, Germany prescribed itself a wage deflation strategy: diverging downward from its own previous, and Euroland's supposed new common, stability norm (see figure 5). As a result, Germany has experienced a very sizeable improvement in its competitiveness position within Europe, which, over time, did not fail to ignite the export engine, leaving Germany with a current account surplus of 8 percent of GDP by 2007. The problem is, of course, that such a policy of wage underbidding cannot work for Euroland as a whole, as one country’s competitiveness gains come at partners’ expense. Ironically, it was precisely this kind of "beggar thy neighbor" competitive devaluation that EMU was supposed to ban forever. (Note here that France and "Euroland excluding Germany” stayed very close to the stability norm, calculated as an ECB-compatible annual 2 percent rise in nominal unit labor costs.) 


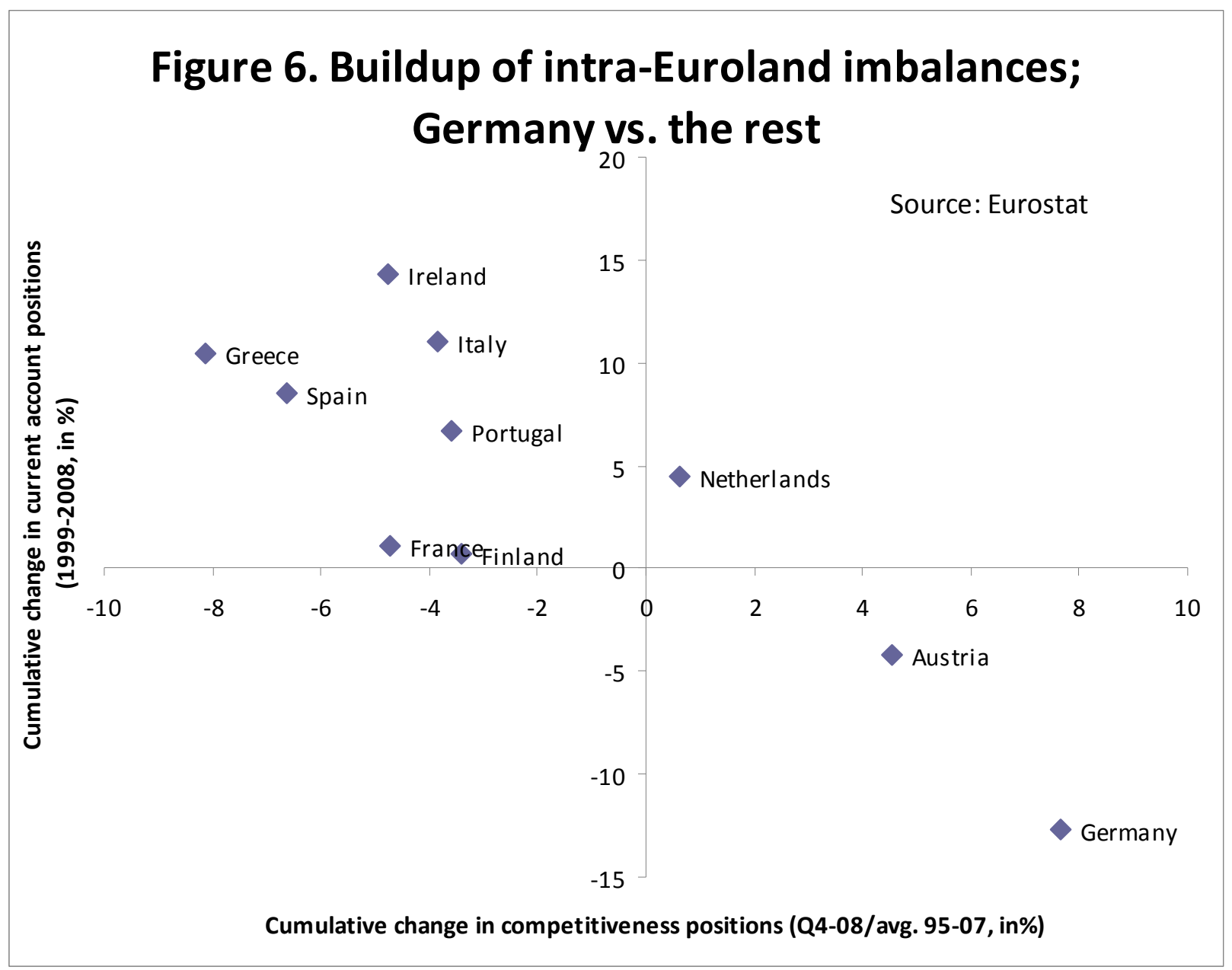

Figure 6 shows changes in real exchange rates relative to the euro area (in terms of unit labor costs) and changes in member states' current account balances since 1999, with changes in current account balances also providing a good indication of changes in bilateral trade balances within Euroland. As Euroland's overall current account position did not change much and remained roughly balanced during this period, this inspired Euroland's policymakers' belief that they had no business with "global imbalances.” Yet, serious intra-area imbalances were caused in this way. All along, countries like Spain had to be grateful that German stagnation also pulled down interest rates, so that strong domestic demand growth would offset the net export drag they experienced thanks to their lead partner's betrayal. As a result, however, the structure of demand 
inside Euroland got seriously distorted, with soaring imbalances creating challenges that are not easily solvable in a monetary union.

At issue here is the supposedly equilibrating working of the "competitiveness channel” inside monetary unions. Official dogma has it that wage-price flexibility should move competitiveness positions in line with relative economic weakness or strength in the union, so that Germany would have seemed justified to have lower wage inflation than everyone else. Unfortunately this doctrine misconstrues a basic tenet of optimum currency area theory, overlooks that wages are also income and, as such, rather vital to domestic demand growth, and also ignores the destabilizing forces unleashed by the Maastricht regime when the competitiveness channel is relied upon to do a job that it cannot accomplish.

Recall that Mundell's (1961) point was that asymmetric shocks may require real exchange rates to adjust, which, in the absence of nominal exchange rates, requires either factors and/or factor prices to be sufficiently mobile and/or flexible to bring this about. As a matter of fact, however, the "global slowdown” of 2001 was surely not an asymmetric shock. Rather, it was a common and largely symmetric shock, which only for failure of Euroland's macro policy regime was not appropriately countered (see "tax-push” above). Yet, it is seriously flawed to interpret Germany’s “cyclical weakness” as an asymmetric shock (see European Commission [2008b: 105-107]) and thereby excuse its wage underbidding strategy when this very strategy caused Germany’s cyclical weakness in the first place.

Do not miss here how the Maastricht regime itself actually amplified divergences in the process. Start with Germany. By pushing its national wage-price inflation trend below everyone else's, with common nominal interest rates across Euroland, Germany ends up having higher real interest rates than its partners - turning Europe’s pre-EMU world upside down! More trouble comes from the SGP requiring budget austerity at a time when domestic demand is struggling anyway. As stagnation is supposed to depress wage growth even more, at least according to the official wage-price flexibility doctrine, this further reinforces domestic demand weakness most directly. Of course, except for small countries, it is hard for net exports to dominate domestic demand. In Germany’s case, in the 2000s it took a historic global boom of five years to finally pull this off in 2006. All along, a booming country like Spain experiences the opposite: relatively low real interest rates, stronger wage growth, and a budgetary position that may even encourage 
tax cuts rather than austerity. For given the SGP's inherent asymmetry, a country already in trouble is disciplined, while a country in a benign fiscal position is not. In short, the Maastricht regime amplified divergences and fed the buildup of imbalances-with lasting competitiveness distortions fatefully excused by the flawed official flexibility doctrine (Bibow 2007a). ${ }^{7}$

Germany has paid a heavy price for this policy blunder in terms of years of stagnating private consumption and protracted domestic demand weakness, pulling down interest rates across Euroland. Following a long boom fired by falling interest rates, Spain pays heavily today as the housing bust is taking its toll. Worst of all, after causing divergence and the buildup of intra-area imbalances, Germany’s wage deflation has left Euroland saddled with the formidable challenge of restoring intra-area competitiveness positions without the possibility of recourse to parity realignments. There is a clear lesson here: to substitute national wage deflation for unionwide macro policy does not help regaining equilibrium, but greatly destabilizes the union.

Before moving on to investigate Europe's response to current crisis, it is appropriate to briefly comment on ECB policy during Euroland's characteristically brief boom of 2006-07. Euroland's belated participation in the record global boom that had started in 2002 was of course, once again, sponsored from abroad, although the euro’s strong appreciation since 2002 had complicated freeloading this time round. Figure 3 (above) revealed the ECB's extraordinarily slow response to the 2001 slowdown, which followed the bank's aggressive tightening binge in 1999-2000. The ECB immediately started tightening in December 2005, as recovery was barely taking hold, habitually treating lost output (years of negative output gaps) as bygones. While hiking somewhat less aggressively this time round, the ECB's policy rate quickly raced ahead of domestic demand, the growth contribution of which barely and only briefly exceeded 2 percent. A conspicuous contrast was then seen again when it came to easing its stance as the economy tanked: the ECB actually still hiked rates in July 2008-almost a year after the start of the crisis. Ignoring the clear message sent by benign core inflation, the ECB got carried away by the commodity price boom of 2008 that briefly pushed headline inflation well

\footnotetext{
${ }^{7}$ The Commission's (2008a) analysis of competitiveness versus real interest rate channels goes seriously astray as a case for more structural reforms of labor markets. Supposedly the expectation is that more flexibility leads to greater wage responsiveness to cyclical positions and thus to accelerated wage divergences between members. This is missing the crucial point that wage divergences can be the cause of cyclical divergence in the first place, while in the absence of any proper asymmetric shock diverging wage trends are wholly unwarranted, as they can only drive the system away from equilibrium and inevitably end with a bust.
} 
above 2 percent. ${ }^{8}$ When headline inflation predictably reversed course a little later, and then even turned negative in the summer of 2009, the ECB was quick to dismiss deflation threats by pointing to more stable core inflation. The ECB's conspicuously asymmetric policies—both words and deeds — are bound to keep Euroland's upswings brief, while making protracted periods of domestic demand stagnation likely. This is especially true when the supposedly stability and growth-enhancing effects of Euroland's fiscal regime are thereby triggered as well. Euroland is laboring under a policy regime featuring an unmistakable anti-(domestic demand) growth bias.

Summing up, our analysis of Euroland's (mal)performance confirms what could be expected on the basis of the regime critique offered beforehand. Essentially, Maastricht meant spreading the "German disease" of mercantilistic export reliance paired with gross negligence regarding domestic demand stabilization. The regime designers' presumption was that exporting the German model would make it work even better, both for Germany and for everyone else, too. In actual fact, however, for Euroland emulating the German model means asymmetric “management” of domestic demand and an antigrowth bias. Ironically, and to Germany’s surprise, exporting the Bundesbank “success story” has undermined its working at home, too, which, in turn, led to severe intra-area divergences and imbalances as Germany adopted a wage deflation strategy. Seen from a global perspective, the Maastricht regime has created a rudderless economic giant that is drifting along, hoping for strong enough export currents to pull it on a sponsored growth course. Jean-Claude Trichet said as much in 2004 when Euroland was last hoping for external sponsors of recovery: “Growth starts with exports, then passes on to investment, and then to consumption. That is the normal sequence for Europe in this phase of the cycle” (Krosta and Major 2004). Needless to say, this policy approach is unlikely to make Euroland a constructive player in fostering recovery from the current global crisis.

\footnotetext{
${ }^{8}$ In the fall of 2005, the ECB argued that low core inflation was about to converge to higher headline inflation, referring to the 2001-02 experience. The argument that core inflation might converge upwards assumes cyclical strength, ignoring that the earlier episode of rising core inflation was actually one of economic weakness, as well as changeover to euro notes and coins (see Bibow 2007c).
} 


\section{TENTH ANNIVERSARY TURMOIL IN EUROPE'S “ZONE OF STABILITY” AND POLICY RESPONSES}

The above performance record (as discussed in section 4) was set before the perfect storm hit. The current global crisis has not provided any evidence for a more favorable verdict on the euro and its guardians. Quite the contrary. On the surface, the euro seems to have brought stability to Euroland as global financial market turmoil could no longer infect intra-Euroland nominal exchange rates. While this factor merely deflected tensions to sovereign debt markets (see below) and may well have enhanced regional currency instability between Euroland members and nonmembers, too, European integration and unity was certainly dealt a heavy blow when national policymakers resorted to nationally focused and mostly uncoordinated policies. Overall, the crisis has confirmed previously diagnosed regime deficiencies: disregard of any need for systematic demand management; ECB asymmetry (inflation phobia paired with deflation complacency); lack of euro Treasury, shared funding facilities, or even fiscal policy coordination; lack of coherent EU financial system policy; lack of instruments to deal with intraarea imbalances; and regional instabilities.

Apparently in full belief of their long-cherished illusion that Euroland was no party in global imbalances, as stability-oriented macro policies had kept Euroland's own house in order, key policymakers ignored the unfolding global financial crisis until the European economy came crashing in on them. Commenting on U.S. rescue measures in response to the Lehman failure, German finance minister Peer Steinbrück declared that "this crisis originated in the United States and is mainly hitting the United States ... [In Europe and Germany, such a package would be] neither sensible nor necessary" (Benoit 2008). The core of Europe had entered recession in the spring, but Mr. Steinbrück and his EU partners remained in complete denial until the fall. ${ }^{9}$ Of course, protracted domestic demand stagnation in Euroland during much of the 1990s and again between 2001 and 2005 contributed to the buildup of global current account imbalances (see Bibow [2007b] and sources quoted there). European banks—in search for higher yields outside perpetually depressed Euroland—had built up large exposures to U.S. “toxic assets,” too.

\footnotetext{
${ }^{9}$ Quite uncharacteristically, the International Monetary Fund had urged its members to set stimulus plans in early 2008, around the time when the United States launched its first stimulus package. European Union authorities, and particularly euro-area central bankers, strongly resisted any such calls, arguing that they would risk undermining the credibility of the Stability and Growth Pact. See Wessel (2008).
} 
A popular idea has it that purchases of U.S. Treasury securities by Asian central banks artificially depressed the U.S. and global interest rates and were therefore responsible for creating the U.S. housing bubble_-and bust. Bibow (2009b) debunks the "global saving glut hypothesis” as being based on flawed loanable funds theory. Instead, the alternative liquiditypreference-theoretical "global dollar glut hypothesis" proposed there emphasizes the role of the U.S. dollar as the key global reserve currency. Neo-mercantilist pursuits in the rest of the world created deflationary pressures in U.S. product and labor markets, prompting sufficiently easy U.S. monetary conditions to nourish the excess U.S. spending needed to sustain global growth. This is not to deny that large positions taken by certain official investors may affect relative yields and asset prices, but in this context it seems far more relevant to consider the role of European banks in determining U.S. and global financial conditions. In particular, given the euro area's fairly balanced current account position overall and a floating euro exchange rate, there was no natural need to find some outlet in U.S. dollar assets-in contrast to certain Asian official investors. Whereas official investors generally favored Treasuries as reserves for their safety and liquidity, more yield-oriented European banks and other private investors focused on the U.S. mortgage credit segment. Either directly or indirectly through their financing of other players, European banks built up highly leveraged exposures to U.S. mortgage-related credit risks, thereby no doubt contributing to the compression of credit risk spreads during the winding phase of their engagements-allowing the U.S. housing bubble to continue as long as it did. In this way, European banks were also left with a sizeable U.S. dollar funding gap that later came to haunt them and the ECB.

So as global imbalances and underlying credit structures started to implode, Euroland actually got hit by a triple whammy. First, although the U.S. subprime mortgage sector may be identified as the initial epicenter of eruptions, through its banking exposures Europe found itself right at the center of the emerging global financial crisis right away. In other words, the crisis did not hit Europe as a proper external shock, but unfolded as an internal crisis right from the start. Moreover, given its lack of domestic defenses, Europe quickly acted as amplifier of the global collapse through both trade and finance channels. Second, intra-Euroland imbalances also began to implode as interbank seizures unraveled credit structures and sent risky asset prices spiraling downward across Euroland. Third, new EU member countries, as well as other countries in the 
region, especially those with large current account deficits that were the legacy of earlier “convergence play,” saw their economies massively destabilized by sudden reversals in international capital flows on top of the collapse of key EU export markets. Given Europe’s very high regional interconnectedness, negative feedback loops from crossborder linkages quickly spread and amplified troubles throughout Europe. World export champion Germany was among the most severely hit European countries, as its sole growth engine-exports-plunged in line with the collapse in global trade. Other countries such as Spain and Ireland (as well as the UK, outside Euroland) got badly hit by bursting housing market bubbles, crushing domestic demand. Crashing currencies and severe economic wreckage in the Eastern European periphery also highlighted old EU members' high exposures to banking system risks in the region, among other things.

Money markets in key global financial centers slid into turmoil on August 9, 2007. ${ }^{10}$ From the beginning, pressures for liquidity support on the ECB were greatest among leading central banks, arising as spillovers from U.S. dollar funding markets and reflecting euro-area banks' dollar funding gap and heavy exposure to U.S. mortgage market risks, largely through conduits and SIVs that had used asset-backed commercial paper markets as their source of (short-term!) finance until those seized up. As money market rates spiked well above policy target rates, the ECB responded by use of large-scale emergency liquidity injections. While the ECB proved flexible in delivering its emergency liquidity-boosting operations, the bank kept up its intentions of another rate hike, having just hiked its policy rates a little before the start of the credit market rout in June 2007, and-after some delay — then actually followed through with it in July 2008. The ECB never saw any conflict between its extensive lender-of-last-resort activities under the umbrella of financial stability policy and its exclusive monetary policy focus on perceived inflation risks. ${ }^{11}$

The ECB’s first rate cut only occurred on October 8, 2008 as part of an internationally coordinated policy easing by key central banks (see Ready and Perry [2008]). Easing its stance more timidly than other central banks, the ECB’s key policy target rate eventually reached 1

\footnotetext{
${ }^{10}$ Market stress had built up since June and was, at this stage, clearly focused on subprime-related losses incurred by investment funds and banks, including Germany's IKB and France's BNP Paribas, for instance.

${ }^{11}$ Throughout the ECB continued to signal its tightening ambitions; see Perry (2007), Atkins and Thornhill (2007), Thesing (2008), and Atkins (2008). With the U.S. Fed aggressively easing since January 2008, the euro appreciated strongly during this phase.
} 
percent by May 2009. Meanwhile, the bank has adapted its operating procedures to fine-tune liquidity injections and to more effectively counter continued money market tensions. Measures in the ECB's "enhanced credit support approach" include: a switch to "fixed-rate full-allotment" tender procedures in its repo operations; an increased share of longer-term refinancing operations (up to 12 months); extensions in acceptable collateral (or "qualitative easing”); inclusion of the European Investment Bank among eligible counterparties; and the decision (announced on May 7 , 2009) to purchase up to €60bn in covered bonds by private issuers (see ECB [2009a]).

These measures have shown some effect. Since the spring, financial conditions have eased significantly, with rates up to one-year maturity effectively pegged at the ECB's tender rate and very short rates closer to its lower deposit rate. Interbank lending, securities issuance, and especially covered bond markets have seen a revival since the ECB's announcement of support. However, while banks are facing strong incentives to recapitalize through the "carry" available on purchasing government bonds, bank lending to the private sector has virtually stalled as banks tightened their lending standards. Overall, the ECB has expanded its balance significantly, though less than the Federal Reserve and Bank of England, while following its incentive to play it safe through diversified lending to large numbers of counterparties and making sure that money markets as a whole do not falter. From the ECB's perspective it is clearly preferable to put early pressure on governments to bail out insolvent institutions directly rather than negotiating loss coverage afterwards for whatever might have ended up on its own balance sheet. In any case, aggressive lending to markets suits the ECB better than lending of last resort to particular institutions facing doubts about their liquidity and/or solvency. As caution in a way requires the ECB to be more aggressive in its approach to financial system support, the bank has arguably been more successful in this area than in its primary domain of monetary policy. A more cautious approach in the latter domain would have required more aggressive and properly preemptive easing. ${ }^{12}$ Restarting bank lending to the private sector represents a

\footnotetext{
${ }^{12}$ Apart from the (Wim Duisenberg) argument that a liquidity trap is best avoided by not easing interest rates in the first place, the ECB again proved itself inventive in justifying delays in policy easing. For instance, board member Lorenzo Bini Smaghi asserted that "a stabler and less-fluctuating monetary policy” would make monetary policy more effective (see Perry [2008]) and that cutting rates sharply now makes it more difficult to raise them back to the right level once recovery takes hold as: "The lower rates are brought, the more likely the central bank will find itself behind the curve" (Perry 2009).
} 
formidable challenge given both impaired bank capital and the tendency of member-state governments to pursue national, rather than EU, objectives.

The tendency to undermine the single market arose even prior to the Lehman collapse when EU governments generally followed a case-by-case approach to strengthening individual bank balance sheets. It became more of a threat in the post-Lehman period when, apart from further individual bank bailouts, governments by force of the situation increasingly turned to national system-wide interventions.

Bank rescues (public capital injections, guarantees for bank liabilities, and measures for relief of impaired bank assets) soared in a number of EU countries following Lehman's fall (see Ecofin [2009a]). For instance, the pan-European bank Fortis was bailed out by Belgium, Luxembourg, and the Netherlands, and the pan-European bank Dexia by Belgium, France, and Luxembourg, while Hypo Real Estate Holding received a loan guarantee by the German government to fend off insolvency. In the UK, an emergency merger between Halifax Bank of Scotland and Lloyds TSB was brokered by the government while the Treasury directly seized Bradford \& Bingley (See Kennedy [2008] and FT.com [2008]). While in the beginning, rapid cooperation between governments in times of crisis scored some points, nationalistic instincts quickly took over, especially as the Irish and German governments issued unilateral guarantees of all deposits in their respective banking systems and pan-European banks were effectively nationalized along national lines. An emergency summit of Euroland (plus UK leaders) in Paris on October 12 (see French EU Presidency [2008]) restarted efforts for a concerted European response. ${ }^{13}$ Governments pledged to prevent failure of any systemically important institution and agreed on certain principles of shoring up their national financial systems. Yet, damage to the single market through governments' recourse to protectionist state aid measures of various forms has continued, keeping the European Commission, as the guardian of the treaties and competition watchdog, on high alert.

\footnotetext{
${ }^{13}$ Inviting the British Prime Minister Gordon Brown acknowledged London's role as Europe’s (and Euroland's) leading financial center. Through this avenue, Brown's proposal for a global summit on reforming the global financial system also provided a key impetus to the G-20 summits held in Washington on November 20, 2008 and London on April 2, 2009. Gordon Brown's recommendable leadership provoked sharp attacks from Germany’s Peer Steinbrueck, intellectually challenged in keeping up with the briskness of events at the time, it seems, who accused the British prime minister for pursuing “crass Keynesianism,” making the revealing comment: "The switch from decades of supply-side politics all the way to a crass Keynesianism is breathtaking” (Parker and Benoit 2008).
} 
The threat of increasing market refragmentation has also led to a new push for writing a "single rule book" and harmonizing pan-EU financial supervision. Following a report initiated in October 2008 by the European Commission and delivered in February 2009 by the "The HighLevel Group on Financial Supervision in the EU” (chaired by Jacques de Larosière), EU leaders endorsed the plan to harmonize micro-prudential supervision and add a new macro-prudential supervision column to EU governance structures in June 2009. In September 2009, the European Commission (2009b) unveiled draft legislation to implement the approved changes. While dayto-day supervision of banks and financial firms would remain with national supervisors, new European supervisory authorities for banking, insurance, and securities sectors (replacing the existing pan-EU coordinating committees) would be charged with developing harmonized rules and common approaches to supervision and ensuring their consistent application. At the macro level, the Commission advocates for the creation of a new European Systemic Risk Board consisting of EU central bank governors and chaired by the ECB president. The proposed board would be charged with the task of monitoring threats to financial stability in the region.

These are laudable attempts to overcome the stark contradiction between nationally segregated supervision over an area of deep (and supposedly ever deeper) financial integration, but the limitations to these endeavors are clear enough, too. In the end, it is inevitably the national finance ministers who are called upon to find solutions to any problems of cross-border financial institutions that may require support from their "deep pockets." In the absence of EU budgetary resources, bail-outs will remain national affairs and the national authorities will continue to stem any intrusions on their fiscal responsibilities accordingly. Therefore, should new emergencies arise under the proposed new governance structure of pan-EU supervisors, similar nationalistic tendencies as observed in the current crisis would likely reoccur. So the real question is whether increased harmonization and coordination between national and EU authorities in this area will yield improved "early warnings" and help prevent emergencies from arising in future without foregoing chances of growth.

Inevitably, the fact that the EU is not a fiscal union also loomed large in the issue of arranging fiscal stimulus packages. Initial calls by the IMF in early 2008 were generally scoffed at. Some EU leaders, Germany's foremost among them, had a very hard time letting their balance-the-budget ambitions go when the world economy was headed for a crisis that they had 
no part in, on their view at least. Starting from a comfortable budget surplus position following its 15-year boom, Spain was the first EU country to implement a fiscal stimulus plan in early 2008 to counter the impact of imploding property markets. Following Lehman's fall, the European Commission proposed a “European Economic Recovery Plan” (Commission 2008b) featuring discretionary budgetary measures of €200bn (1.5 percent of EU GDP) in late November 2008, which was approved at the European Council in Brussels on December 11-12, 2008. Concerning fiscal stimulus action at the union level, it was agreed that the European Investment Bank would increase its funding of immediate actions in 2009-10 by €30bn, while the bulk of $€ 170 \mathrm{bn}$ in the recovery plan would (have to) come from the member states (see European Council [2009] and IMF [2009]).

Given differing budgetary starting positions constraining each individual country’s room for maneuvering, the largest national stimulus package actually came from Germany, where leaders finally woke up to the fact of a looming general election in September 2009. Contrary to the idea that Germany was once again made EU paymaster for other countries' failures to put their fiscal houses in order during good times, Germany’s more sizeable fiscal stimulus in response to the crisis (1.5 percent of GDP in 2009 and 2 percent of GDP in 2000) should be seen as partial compensation for the country’s notorious freeloading on exports through competitiveness gains in prior years when mindless fiscal retrenchment suffocated German domestic demand (and imports from partners). Compensation is only partial though because of the lingering challenge to restore competitiveness positions within Euroland and the lasting pressures on the partners' budgets this has created. By comparison, it seems more than appropriate that, for instance, France enacted a somewhat smaller stimulus given that its budgetary policies had provided support to French and Euroland domestic demand in prior years. Italy has been excused for its negligible stimulus in view of the country's high debt ratio; its deficit ratio will now likely be overtaken by Germany’s and France’s in coming years. Spain enacted a series of overall sizeable stimulus packages, but, in view of the massive turnaround in its fiscal fortunes that saw private debts plentifully amassed during boom years quickly morphing into public debts when crisis hit Spain, is now headed for a very "early exit” from stimulus - a brutal awakening for the former star performer and fiscal paragon (European Commission 2009a). In fact, Spain’s recent announcement of VAT rate hikes in 2010 (following 
hikes in indirect taxes on tobacco and fuel in 2009) heralds the unappealing things about to make their return to Euroland in the near future: fiscal retrenchment featuring "tax-push inflation” (see FT.com [2009]).

For in advocating "timely, temporary, targeted, and coordinated” national budgetary stimulus packages, the Commission (2008c) has not tired in holding up the SGP as the "credible framework" for fiscal policies, emphasizing that the pact will be "applied judiciously, ensuring credible medium-term fiscal policy strategies” with timely corrective action needed by members to avoid penalties under the EDP. The ECB, too, has made it clear what is expected from member states at the fiscal front: "The structural adjustment process should start, in any case, not later than the economic recovery and the consolidation efforts should be stepped up in 2011. Structural consolidation efforts will need to exceed significantly the benchmark of 0.5 percent of GDP per annum set in the SGP. In countries with high deficits and/or debt ratios, the annual structural adjustment should reach at least 1 percent of GDP” (ECB 2009b). ${ }^{14}$ If members are not sufficiently forthcoming in their consolidation efforts to meet the ECB's expectations, the punishment would take the form of an early monetary tightening, the ECB warned (Bini Smaghi 2009, for instance).

Of course the SGP is not an instrument for proper coordination of policies, but foremost a disciplining instrument, one of those supposed "safeguards" to protect "sound money" from fiscal profligacy. Another of those supposed safeguards—-the "no bail-out clause"-haunted Euroland in early 2009, too, with speculations about an impending euro break-up leading to soaring interest rate spreads between Euroland members. Ireland, another former star performer that has seen a sharp turnaround in its economic and fiscal fortunes with several rating downgrades on its sovereign debts since 2008, was hit especially hard (as was Greece). This time around, the speculative attacks hitting sovereign debt rather than currency markets was fended off as Germany’s finance minister declared that “the euro-region treaties don't foresee any help for insolvent countries, but in reality the other states would have to rescue those running into difficulty” (Benoit 2009). The no bail-out clause as an obstacle to stability-rather than safeguard!-is symptomatic for experiences that highlighted just how ludicrous the design of Europe’s monetary union really is.

\footnotetext{
${ }^{14}$ And this time round the ECB even anticipates that "increases in indirect taxation and administered prices may be stronger than currently expected owing to the need for fiscal consolidation in the coming years” (ECB 2009).
} 
In this regard, Euroland members are even worse off than other EU members. For nonEuroland EU members in financial difficulty are at least eligible for EU financial (balance of payments) assistance, and the EU even agreed in May 2009 to double the lending ceiling for its support facility from €25bn to €50bn. Yet, this cannot gloss over the fact that EU support for its new members in Eastern Europe (and the neighboring region), among the most severely hit emerging-market economies in the current global crisis, has proven vastly insufficient. The EU support facility has been used to provide medium-term assistance to Hungary, Latvia, and Romania (Ecofin 2009b). However, this occurred as part of broader assistance from the IMF (as "stand-by arrangements," whereas Poland has an arrangement under the Fund's "flexible credit line" facility). Ironically, the experience of the crisis may have both raised the willingness for new EU members to accelerate euro adoption, but also greatly reduced their ability to meet the necessary criteria to be allowed in. ${ }^{15}$ Especially in view of the stark deterioration in public finances in crisis-hit new-member countries, such ambitions may have been pushed back for many years.

Once again, Euroland appears to be the laggard in emerging from the current global crisis. The Euroland economy may have turned the corner by midyear 2009, but following five consecutive quarters of negative (qoq) domestic demand growth, the homemade forces for a sustainable recovery look decidedly weak. ${ }^{16}$ All Euroland members except Cyprus, Luxembourg, and Finland have budget deficits in excess of 3 percent of GDP. Already operating under EDP, Greece is expected to squeeze its deficit below 3 percent by 2010, France and Spain by 2012, and Ireland by 2013. At least in parts of Euroland, "exit" from crisis-related stimulus measures started before any recovery. Contrary to declarations made at the latest G-20 leaders summit in Pittsburgh, PA, Euroland seems set for another protracted fiscal consolidation "no matter what"-in the hope that exports to the rest of the world will be strong enough. International cooperation is profoundly hindered by the fact that Euroland's authorities continue to view themselves as "victims" of external events rather than as key players in bringing a triple whammy of enormous economic wreckage upon Europe that will pose a challenge to European integration for years to come. Germany's "export-oriented growth model” continues to stand

\footnotetext{
${ }^{15}$ At least in the case of Iceland the crisis has given rise to the crisis-hit country seeking EU membership.

${ }^{16}$ Germany recorded positive (qoq) growth already in the second quarter, once again driven by a massive net exports contribution (with imports dropping more sharply than exports).
} 
right at the heart of Europe's problem: effectively exporting stagnation, or worse, to Euroland and beyond.

\section{SUMMARY}

On the euro's tenth anniversary, Euroland (and the wider Europe) has little else to be cheerful about than price stability, which stands "above all else" and of which there can never be enough, of course, even as headline HICP for Euroland actually fell to minus 0.7 percent in the summer of 2009. Arguably, nothing else was to be expected though from a "price stability above all else" policy regime designed by German central bankers. By design there is no place within the Maastricht regime for any authority minding the domestic demand store. The peculiar ideology that price stability, fiscal austerity, and structural reform (essentially, wage compression) may be enough to generate growth overlooks the vital part that export surpluses used to play in the German "homeland of stability-oriented policy" wisdom. The point is that the world is a closed economy and the European economy too large to rely on mercantilism for its growth. Making matters worse still, Germany—as a monetary union member—supercharged its national mercantilism, thereby causing serious intra-area imbalances and preparing the ground for internal crises of calamitous dimensions. Ironically, beggar-thy-neighbor policies such as these were exactly what the euro was meant to ban forever. For the next ten years of its young life the euro will have to live with the legacies of Germany's "restored” competitiveness.

Key authorities in Europe seem wholeheartedly resistant to learning and hang on to a fiction that blames the rest of the world for their homemade misfortunes. In truth, the EU and particularly Euroland were very far from keeping their own house in order when crisis struck. Euroland had not only contributed handsomely to the buildup of global imbalances since the 1990s and it also came to experience their implosive unwinding as an internal crisis from the beginning. This was because of large exposures in European banks to U.S. mortgage credit risk, engagements that had helped financing the U.S. housing bubble, but hit Europe with a vengeance as a severe European banking crisis as soon as the U.S. bubble burst. In addition, having nourished its own homemade intra-Euroland and intra-EU imbalances under stability-oriented guardianship, turmoil in Europe's supposed "zone of stability" was further aggravated by the 
simultaneous implosion of these "purely" homegrown troubles, hitting as a "triple whammy" perfect storm. More mindless fiscal austerity, rigidity waffling, and "price stability above all else” propaganda are not the solution to anything. Someone has to start minding Europe's domestic demand store. Steps towards a fiscal union to back the euro are warranted. Proper crisis diagnosis is crucial now. As long as key European authorities remain in denial there is little to hope. The euro may not break, but make members go broke together instead. 


\section{REFERENCES}

Allsopp, C., and D. Vines. 1998. “The Assessment: Macroeconomic Policy after EMU.” Oxford Review of Economic Policy 14(3): 1-23.

Almunia, J. 2008. “Foreword.” in EMU@10-Successes and Challenges after Ten Years of Economic and Monetary Union. Brussels: European Commission.

Arestis, P., and M. Sawyer. 2001. The Euro: Evolution and Prospects. Aldershot: Edward Elgar.

Atkins, R. 2008. “ECB reaffirms inflation stance.” FT.com, September 16.

Atkins, R., and J. Thornhill. 2007. “ECB still pursuing rate rise policy.” FT.com, September 8.

Begg, D., F. Canova, P. De Grauwe, A. Fatás, and P.R. Lane. 2002. "Surviving the slowdown.” Monitoring the ECB, No. 4. Washington, DC: Center for Economic Policy Research (CEPR).

Benoit, B. 2008. “Germany sees an end to U.S. hegemony.” FT.com, September 26.

—. 2009. “Germany ready to help eurozone members.” FT.com, February 18.

BIS. 2002. 72nd Annual Report. Basle: Bank for International Settlements

Bibow, J. 1998. “Geldpolitik als Inflationsursache?” in A. Vilks and B.P. Priddat (eds.), Wirtschaftswissenschaften und Wirtschaftswirklichkeit. Marburg: Metropolis.

. 2001. "Making EMU Work: Some Lessons from the 1990s." International Review of Applied Economics 15(3): 233-259.

_ 2002. "The Markets versus the ECB and the Euro's Plunge.” Eastern Economic Journal 28(1): 45-57.

. 2004. "Assessing the ECB's Performance since the Global Slowdown-A Structural Policy Bias Coming Home to Roost?” Working Paper 409. Annandale-on-Hudson, N.Y.: The Levy Economics Institute of Bard College.

- 2005. "Issing fails to justify claims that ECB policy flagged up likely threats.” Letter to the Editor, Financial Times, December 19.

. 2006. "Inflation persistence and tax-push inflation in Germany and the Euro area: A symptom of macroeconomic mismanagement?” Studies 1/2006. Düsseldorf, Germany: Institut fuer Makrooekonomie und Konjunkturforschung (IMK). 
- 2007a. "How the Maastricht Regime Fosters Divergence as Well as Fragility.” in P.

Arestis, E. Hein, and E. Le Heron (eds.), Monetary Policies-Modern Approaches.

Basingstoke, UK: Palgrave. [Originally published as Working Paper 460. Annandale-onHudson, N.Y.: The Levy Economics Institute of Bard College.]

. 2007b. "Global Imbalances, Bretton Woods II, and Euroland's Role in All This.” in J. Bibow and A. Terzi (eds.) Euroland and the World Economy-Global Player or Global Drag? Basingstoke, UK: Palgrave. [Originally published as Working Paper 486.

Annandale-on-Hudson: The Levy Economics Institute of Bard College].

—. 2007c. “The ECB—How Much of a Success Story, Really?” in E. Hein, J. Priewe, A. Truger (eds.), European Integration in Crisis. London: Metropolis.

. 2009a. "On the origin and rise of central bank independence in West Germany." The European Journal of the History of Economic Thought 16(1): 155-190.

. 2009b. Keynes on Monetary Policy, Finance and Uncertainty: Liquidity Preference Theory and the Global Financial Crisis. London: Routledge.

Bini Smaghi, L. 2009. “An Ocean Apart? Comparing Transatlantic Responses to the Financial Crisis.” Speech, Rome, September 10-11. Available at: http://www.ecb.int/press/key/date/2009/html/sp090911.en.html

Council of the European Union (Ecofin). 2009a. “Annex to the Council (Ecofin) Report to the June 18-19 European Council on the Effectiveness of Financial Support Schemes: Report of the Task Force on Reviewing the Effectiveness of Financial Support Measures.” Brussels: Council of the European Union (Ecofin).

- 2009b. "Joint statement by the Presidency of the Ecofin Council and the Commission on providing EU medium-term financial assistance to Romania.” Brussels, March 25.

Available at:

http://europa.eu/rapid/pressReleasesAction.do?reference=IP/09/475\&format=HTML\&ag ed $=0$ \&language $=$ EN\&guiLanguage $=$ en

Darvas, Z., and J. Pisani-Ferry. 2008. “Avoiding a New European Divide.” Policy Brief 2008/10. Brussels: Bruegel.

Dinmore, G., and J. Thornhill. 2008. “Europe looks for allies against inflation.” FT.com, September 9.

Dolan, M., and N. Waki. 2008. “ECB’s Trichet holds the line on rates, inflation.” Reuters, January 24. 
Duisenberg, W. 2001. “Quotes from the European Parliament's 'Committee on Economic and Monetary Affairs’ Monetary Dialogue.” March. Available at:

http://www.europarl.europa.eu/comparl/econ/pdf/emu/speeches/20010305/duisenberg/ful $\underline{\text { ltxt/default_en.pdf }}$

Dyson, K., and K. Featherstone. 1999. The Road to Maastricht: Negotiating EMU. New York: Oxford University Press.

European Central Bank (ECB). 1999. “The stability-oriented monetary policy strategy of the Eurosystem.” Monthly Bulletin, January.

_. 2009a. “The implementation of monetary policy since August 2007.” Monthly Bulletin, July.

—. 2009b. "Editorial.” Monthly Bulletin, September.

European Commission. 2000. “The EU economy: 2000 review.” European Economy 71(January).

_.2008a.EMU@10-Successes and Challenges after Ten Years of Economic and Monetary Union. Brussels: European Commission, Economic and Financial Affairs.

. 2008b. "Labour market and wage developments in 2007." European Economy 5(October).

_. 2008c. “A European Economic Recovery Plan, November 16.” Communication. Brussels: European Commission, Economic and Financial Affairs.

—. 2009a. "Public finances in EMU—2009.” European Economy 5(June).

. 2009b. "Commission adopts legislative proposals to strengthen financial supervision in Europe.” IP/09/1347, September 23. Brussels: European Commission, Economic and Financial Affairs. Available at: http://europa.eu/rapid/pressReleasesAction.do?reference=IP/09/1347\&format=HTML\&a ged $=0$ \&language $=$ EN\&guiLanguage $=$ en

European Council. 2009. "Presidency Conclusions, Brussels European Council, December 1112.” 17271/1/08 REV 1, issued February 13. Brussels: European Council.

FT.com. 2008. “Dexia receives euro 6.4bn capital injection.” September 30.

—. 2009. "Spain raises taxes to tackle deficit.” September 28. 
French EU Presidency. 2008. "Summit of the euro area countries: declaration on a concerted European action plan of the euro area countries.” Paris, October 12. Available at: http://www.eu2008.fr/PFUE/lang/en/accueil/PFUE-10_2008/PFUE12.10.2008/sommet_pays_zone_euro_declaration_plan_action_concertee.html

Girsch, H., and H. Lehment. 1981. "Monetary policy: Does independence make a difference?The German experience.” ORDO 32: 3-16.

Goodhart, C.A.E. 1998. "The two concepts of money: implications for the analysis of optimal currency areas.” European Journal of Political Economy 14(3): 407-432.

Henning, C.R. 1994. Cooperating with Europe’s Monetary Union. Washington, DC: Institute for International Economics.

International Monetary Fund (IMF). 2009. "Update on fiscal stimulus and financial sector measures.” Note, April 26.

Issing, O. 2003. "Europe and the U.S.: Partners and Competitors—New Paths for the Future.” Speech, German British Forum, London, October 28. Available at: http://www.ecb.int/key/03/sp031028.htm

Johnson, P.A. 1998. The Government of Money-Monetarism in Germany and the United States. Ithaca, NY and London: Cornell University Press.

Katzenstein, P.J. 1987. Policy and Politics in West Germany: The Growth of a Semisovereign State. Philadelphia: Temple University Press.

Kenen, P. 1995. Economic and Monetary Union in Europe-Moving beyond Maastricht. Cambridge, UK: Cambridge University Press.

Kennedy, S. 2008. “European lenders get bailouts as U.S. crisis spreads.” Bloomberg, September 29.

Keynes, J.M. 1923 [1971]. A Tract on Monetary Reform, Collected Writings of John Maynard Keynes, volume 4. London: Macmillan.

-1932. An End of Reparations? The Collected Writings of John Maynard Keynes, volume 18. Cambridge, UK: Cambridge University Press.

Kregel, J. 1999. "Can EMU combine price stability with employment and income growth?” Eastern Economic Journal 25(1): 35-47.

Krosta, A., and T. Major. 2004. "Reforms good for growth with Europe on track for recovery, Interview with J.-C. Trichet.” Financial Times, April 23. 
Marsh, D. 1992. The Bundesbank: The Bank that Rules Europe. London: Mandarin.

Mundell, R.A. 1961. “A theory of optimum currency areas.” American Economic Review 51(4): 657-675.

Parker, G., and B. Benoit. 2008. “Berlin hits out at ‘crass’ UK strategy.” FT.com, December 10.

Perry, J. 2007. “ECB signals rate increase is still likely.” Wall Street Journal, August 23.

—. 2008. "ECB stays course on pace of easing.” Wall Street Journal, November 19.

2009. "ECB explains reasons for caution on rates: No deflation threat, fear of a new bubble guide policy.” Wall Street Journal, January 22.

Ready, S., and J. Perry. 2008. “Central banks cut rates world-wide.” Wall Street Journal, October 8.

Thesing, G. 2008. “ECB vows to fight inflation even as economy contracts.” Bloomberg, August 14.

Tietmeyer, H. 1991. “The role of an independent central bank in Europe.” in P. Downes and R. Vaez-Zadeh (eds.), The Evolving Role of Central Banks. Washington, DC: International Monetary Fund.

Vocke, W. 1973. Memoiren. Stuttgart: Deutsche Verlags-Anstalt.

Wessel, D. 2008. “Trichet: No fiscal stimulus here, please.” Wall Street Journal, September 7.

Wolf, M. 2007. “The pain in Spain will follow years of rapid economic gain.” Financial Times, March 27. 